\title{
ADMISSION HYPERGLYCEMIA IN CRITICALLY ILL PATIENTS WITH SEPSIS IN MEDICAL ICU; ROLE OF INSULIN RESISTANCE AND ITS RELATION TO OUTCOME
}

\author{
By \\ Mohammed G. Hassan, Gamal A. Badr, Ahmed M. Al-Ashker and \\ Ashraf A. Ahmed* \\ Departments of Internal Medicine and Clinical Pathology*, Faculty of Medicine, Al-Azhar \\ University \\ Corresponding author: Mohammed Galal Mohamed Hassan,
}

Mobile: 01114446941, E-mail: dr.mohamedgala121@gmail.com

\begin{abstract}
Background: Hyperglycemia has long been recognized as a common occurrence in critically ill patient, even without history of diabetes mellitus (D.M).

Objective: To investigate the role of insulin resistance in patients with sepsis admitted to medical intensive care unit (ICU) with acute hyperglycemia and its relation to 30 days outcome.

Patients and Methods: This study was conducted on 100 adult septic patients who were admitted to medical I.C.U: 80 patients with evidence of hyperglycemia and 20 patients with euglycemic state.

Results: Non-significant difference was found according to mean values of $\mathrm{Na}+\mathrm{K}+$, creatinine, total leukocytic count (TLC), HB\%, platelets (PLT), alanine transaminase (ALT), aspartate transaminase (AST). On the other hand, the hyperglycemic group showed a significant increase regarding mean value of $\mathrm{HbA} 1 \mathrm{c}$ compared to control group. The comparative study between the 2 groups revealed a significant increase of mean value of C-reactive protein (CRP) in the hyperglycemic group compared to the control group. As regards the vital signs, the hyperglycemic group showed a significant increase in mean values of systolic blood pressure, diastolic blood pressure, mean arterial pressure (MAP) and heart rate (HR) compared to the control group. There was no significant difference between the 2 groups regarding temperature and RR. This study showed statistically significant decrease in mean values of Glasgow Coma Score (GCS) in hyperglycemic group compared to control group, while Acute Physiology and Chronic Health Evaluation II (APACHE II) and quick Sepsis Related Organ Failure Assessment (qSOFA) showed a significant increase in hyperglycemic group compared to control group. The mean values of ABG parameters revealed no statistically significant difference between the 2 groups. On the other hand, mean values of random blood sugar (RBS) and insulin resistance (IR) showed a statistically significant increase in hyperglycemic group compared to control group. The comparative study between the 2 groups showed a significant increase in mean values of hyperglycemic group compared to control group according to duration of ICU stay (days), insulin therapy, acute kidney injury (AKI) and outcome, and non-significant difference according to Interstitial lung disease (ILD), chronic lung disease (CLD), chronic kidney disease CKD, stroke, pneumonia, Ischemic heart disease (IHD), chronic obstructive pulmonary disease (COPD) and heart failure (HF).
\end{abstract}

Conclusion: Stress hyperglycemia with high insulin resistance is strongly associated with adverse outcomes in patients with sepsis who were admitted to the medical ICU. Sepsis patients with hyperglycemia showed increased incidence of mortality and AKI.

Key words: Hyperglycemia, sepsis, ICU, insulin resistance. 


\section{INTRODUCTION}

Hyperglycemia has long been recognized as a common occurrence in critically ill patient, even without history of diabetes mellitus (D.M). Although there are few studies investigating the prevalence of stress hyperglycemia, one study reported that $38 \%$ of patients admitted to general hospitals had hyperglycemia episodes, $16 \%$ of which had no previous history of D.M (Fayed et al., 2015).

Stress hyperglycemia is usually defined as nearly detected hyperglycemia $>200 \mathrm{mg} / \mathrm{dl}$ which resolve after resolution of acute illness. Two diagnostic categories of stress hyperglycemia have been reported: Hospital related hyperglycemia according to (ADA) consensus definition F.B.S $\geq 126 \mathrm{mg} / \mathrm{dl}$ or R.B.S $>200 \mathrm{mg} / \mathrm{dl}$ without evidence of previous D.M. Preexisting D.M with deterioration of preillness glycemic control (Pakhetra et al., 2016).

Stress hyperglycemia is thought to be the body's adaptive response to stress on injury. However, recently it has been found that hyperglycemia in critically ill patients can pose a greater risk of mortality and morbidity. Furthermore, the evidence suggests that insulin therapy to control stress hyperglycemia can reduce mortality and improve overall patient outcome (Robba and Bilotta, 2016).

Hospital related hyperglycemia results from activation of insulin counter regulatory hormones caused by stress. Glycemic control is further impaired by administration of drugs which increase insulin resistance such as catecholamines and steroids.
Severe hyperglycemia is a catabolic state associated with adverse electrolytes and volume shifts. Mechanisms include high tissue and circulatory concentrations of inflammatory cytokines and reduction of glucose uptake capacity in peripheral tissues (Pakhetra et al., 2016).

There is increased hepatic glucose production, depressed glycogenesis and glucose intolerance. Increased production of counter regulatory hormones lead to increased insulin resistance, thereby decreasing insulin action (Nakamura et al., 2012).

The role of insulin resistance is most likely via the modification of signaling properties of insulin receptor substrates. Insulin resistance ultimately promote a catabolic state leading to lipolysis and lipotoxicity which further aggravate the inflammatory state especially in critically ill patients (Spindler et al., 2016).

The present study aimed to study the effect of acute hyperglycemia and the possible mechanisms regarding insulin resistance in patients with sepsis admitted to medical I.C.U. and its relation to 30 days outcome.

\section{PATIENTS AND METHODS}

This study was a prospective study, which was conducted on 100 adult sepsis patients who were admitted to medical I.C.U, 80 patients with evidence of hyperglycemia and 20 patients with euglycemic state. The study included patients $\geq 18$ and $<65$ years old; where patients receiving steroid therapy or/and already started steroid on admission. 
At enrollment, patients were subjected to the following: history taking and clinical examination, laboratory work-up, blood sugar level, C-peptide, insulin level, $\mathrm{Hb}$ A1c, serum CRP, CBC, ABG, kidney function tests and liver function tests.

The diagnosis of sepsis depended on the definition of a college of chest physician/society of critical care medicine consensus conference (Chakraborty et al., 2020) by an identifiable site of infection and evidence of systemic inflammatory response.

Admission hyperglycemia was defined as the first measurement of glucose within a time window of 4 hours before and up to 4 hours after admission.

Blood glucose was categorized as: euglycemia (70-140 $\mathrm{mg} / \mathrm{dl})$, mild hyperglycemia (141-199 mg/dl), and severe hyperglycemia $\geq 200 \mathrm{mg} / \mathrm{dl}$ (Pakhetra et al., 2016).

\section{Assessment of sepsis was done according to:}

APACHE II score: ("Acute Physiology and Chronic Health Evaluation II") is a severity-of-disease classification system applied within 24 hours of admission of a patient to ICU. The point score was calculated from a patient's age and 12 routine physiological measurements:

qSOFA score: The quick SOFA Score is a simplified version of the SOFA Score as an initial way to identify patients at high risk for poor outcome with infection.

The score ranged from 0 to 3 points. The presence of 2 or more qSOFA points near the onset of infection was associated with a greater risk of death or prolonged intensive care unit stay.
C-peptide: Enzyme immunoassay for the quantitative determination of circulating C-peptide concentrations in human serum.

\section{Specimen collection and preparation:}

The specimens were blood serum in type and the usual precautions in the collection of venipuncture samples were observed. For accurate comparison to established normal values, a fasting morning serum sample was obtained. The blood was collected in a plain red-top venipuncture tube without additives, and blood was allowed to clot. The specimens were centrifuged to separate the serum from the cells.

C-Peptide was not stable in serum basis, so samples were used as fresh as possible, and refrigerated at $2-8^{\circ} \mathrm{C}$ for a maximum period of one day only. If the specimens were assayed within this time, the samples were stored at temperature of $-20^{\circ} \mathrm{C}$ for up to 30 days. Repetitive freezing and thawing were avoided. When assayed in duplicate, $0.100 \mathrm{ml}$ of the specimen was required.

\section{Sensitivity:}

The sensitivity (detection limit) was ascertained by determining the variability of the $0 \mathrm{ng} / \mathrm{ml}$ serum calibrator and using the 2SD (95\% certainty) statistic to calculate the minimum dose. The assay sensitivity was found to be $0.03 \mathrm{ng} / \mathrm{ml}$.

Enzyme immunoassay was used for the quantitative determination of human insulin concentrations in human serum.

The sensitivity (detection limit) was ascertained by determining the variability of the $0 \mathrm{uIU} / \mathrm{ml}$ serum calibrator and using the 2SD (95\% certainty) statistic to 
calculate the minimum dose. The assay sensitivity was found to be $2.0 \mu \mathrm{IU} / \mathrm{ml}$.

HOMA test as a measurement of insulin resistance based on fasting glucose and insulin concentrations (homeostasis model assessment HOMAIR), Quantitative Insulin Sensitivity Check index, QUICKI)), which was suitable for epidemiological studies where the large number of cases compensated for the limited precision of insulin measurements when compared with dynamic tests.

Fasting insulin determinations strongly depended upon the precision of the assay, and small errors greatly affected these indices, especially when calculated on a single determination. The HOMA index has been extensively used to investigate insulin resistance in NAFLD and represents the only method used so far in CHC.

HOMA-IR was calculated according to the formula: fasting insulin $(\mu \mathrm{U} / \mathrm{L}) \mathrm{x}$ fasting glucose $(\mathrm{nmol} / \mathrm{L}) / 22.5$.

\section{Statistical analysis:}

Recorded data were analyzed using the statistical package for social sciences, version 20.0 (SPSS Inc., Chicago, Illinois, USA). Numerical data will be explored for normality by checking the distribution of data and using tests of normality (Kolmogorov-Smirnov and Shapiro-Wilk tests). Data will be presented as mean, standard deviation (SD), median and range values. For parametric data, Student's t-test will be used to compare between the two groups. For nonparametric data, Mann-Whitney $U$ test will be used to compare between the two groups. Chi-square $\left(\mathrm{X}^{2}\right)$ test of significance was used in order to compare proportions between qualitative parameters. The confidence interval was set to $95 \%$ and the margin of error accepted was set to $5 \%$. So, P-value was considered significant when P-value $\leq 0.05$.

\section{RESULTS}

This prospective study enrolled 100 adult sepsis patients who were admitted to medical I.C.U. They were divided into control group of 20 cases with euglycemic state, and study group of 80 cases with hyperglycemic state.
Statistically significant difference was found between groups according to demographic data and $\mathrm{ABG}$, but showed statistically significant increase in mean of hyperglycemia group compared to control group according to CRP (Table 1). 
Table (1): Comparison between control group and hyperglycemic group according to demographic data, CRP and ABG

\begin{tabular}{|c|c|c|c|}
\hline Demographic data Groups & $\begin{array}{c}\text { Control Group } \\
(\mathbf{n}=20)\end{array}$ & $\begin{array}{l}\text { Hyperglycemic } \\
\text { Group }(\mathbf{n}=80)\end{array}$ & p-value \\
\hline \multicolumn{4}{|l|}{ Age (years)\# } \\
\hline Mean \pm SD & $54.45 \pm 9.93$ & $53.33 \pm 8.61$ & \multirow{2}{*}{0.615} \\
\hline Range & $33-64$ & $23-65$ & \\
\hline \multicolumn{4}{|l|}{$\operatorname{Sex}^{\dagger}$} \\
\hline Female & $11(55.0 \%)$ & $32(40.0 \%)$ & \multirow{2}{*}{0.226} \\
\hline Male & $9(45.0 \%)$ & $48(60.0 \%)$ & \\
\hline C-reactive protein + & \multirow{3}{*}{$\begin{array}{c}170(65) \\
45-309\end{array}$} & \multirow{3}{*}{$\begin{array}{c}150(90) \\
6-395\end{array}$} & \multirow{3}{*}{$0.037^{*}$} \\
\hline Median (IQR) & & & \\
\hline Range & & & \\
\hline Arterial blood gases & \multirow{4}{*}{$\begin{array}{l}63(15) \\
43-90\end{array}$} & \multirow{4}{*}{$\begin{array}{c}65(19) \\
16-99\end{array}$} & \multirow{4}{*}{0.651} \\
\hline $\mathrm{PaO2}$ (mmhg) & & & \\
\hline Median (IQR) & & & \\
\hline Range & & & \\
\hline \multicolumn{4}{|l|}{ PH\# } \\
\hline Mean \pm SD & $7.37 \pm 0.10$ & $7.28 \pm 0.18$ & \multirow{2}{*}{0.034} \\
\hline Range & $7.14-7.47$ & $6.8-7.69$ & \\
\hline \multicolumn{4}{|l|}{ Paco2 (mmhg) } \\
\hline Median (IQR) & $37(11)$ & $38(22)$ & \multirow{2}{*}{0.929} \\
\hline Range & $16-55$ & $12-188$ & \\
\hline \multicolumn{4}{|l|}{ HCO3 (meq/L)\$ } \\
\hline Median (IQR) & $23(8)$ & $21(7)$ & \multirow{2}{*}{0.245} \\
\hline Range & $14.9-40$ & $4.3-36$ & \\
\hline
\end{tabular}

Using: \#Independent Sample t-test; $\uparrow$ Chi-square test; $\$$ Mann-Whitney test

A statistically significant increase was found in mean of hyperglycemia group compared to control group according to HbA1c (Table 2). 
Table (2): Comparison between control group and hyperglycemic group according to lab. Chemistery

\begin{tabular}{|c|c|c|c|}
\hline $\begin{array}{ll}\text { Lab chemistery } & \text { Groups } \\
\end{array}$ & $\begin{array}{l}\text { Control } \\
\text { Group } \\
(\mathbf{n}=20)\end{array}$ & $\begin{array}{c}\text { Hyperglycemic } \\
\text { Group }(n=80)\end{array}$ & p-value \\
\hline \multicolumn{4}{|l|}{$\mathrm{Na}+(\mathrm{meq} / \mathrm{L}) \#$} \\
\hline Mean \pm SD & $137.45 \pm 9.81$ & $138.21 \pm 5.87$ & \multirow{2}{*}{0.66} \\
\hline Range & $128-172$ & $128-150$ & \\
\hline \multicolumn{4}{|l|}{ K+ (meq/L)\# } \\
\hline Mean \pm SD & $3.94 \pm 0.55$ & $4.20 \pm 1.36$ & \multirow{2}{*}{0.407} \\
\hline Range & $3.1-5.2$ & $2.7-9.9$ & \\
\hline \multicolumn{4}{|l|}{ Creatinine $(\mathrm{mg} / \mathbf{1 0 0 m}) \neq$} \\
\hline Median (IQR) & $3(2)$ & $3(3)$ & \multirow{2}{*}{0.671} \\
\hline Range & $0.6-6.9$ & $0.5-13$ & \\
\hline \multicolumn{4}{|l|}{ Total leukocytic count (TLC) (cmm3)\# } \\
\hline Mean \pm SD & $17.36 \pm 3.79$ & $17.12 \pm 4.96$ & \multirow{2}{*}{0.841} \\
\hline Range & $13.3-28$ & $12-34.5$ & \\
\hline \multicolumn{4}{|l|}{ Hb A 1 ct } \\
\hline Median (IQR) & $5(1.5)$ & $7(2)$ & \multirow{2}{*}{$0.002^{*}$} \\
\hline Range & $3.9-6.3$ & $2.4-10.5$ & \\
\hline \multicolumn{4}{|l|}{ HB\% \% } \\
\hline Median (IQR) & $10(4)$ & $10(3)$ & \multirow{2}{*}{0.823} \\
\hline Range & $2.2-15$ & $3.7-17$ & \\
\hline \multicolumn{4}{|l|}{ Platelets $(\mathrm{cmm} 3) \$$} \\
\hline Median (IQR) & $225(111)$ & $224(110)$ & \multirow{2}{*}{0.853} \\
\hline Range & $85-490$ & $70-435$ & \\
\hline \multicolumn{4}{|l|}{ Alanine transaminase (ALT) (U/L) } \\
\hline Median (IQR) & $77(80)$ & $62(101)$ & \multirow{2}{*}{0.594} \\
\hline Range & $10-319$ & $10-450$ & \\
\hline \multicolumn{4}{|l|}{ Aspartate transaminase (AST) (U/L) } \\
\hline Median (IQR) & $90(140)$ & $81(115)$ & \multirow{2}{*}{0.417} \\
\hline Range & $16-452$ & $10-466$ & \\
\hline
\end{tabular}

Using: \#Independent Sample t-test; $₫$ Mann-Whitney test

A statistically significant decrease was found in mean of hyperglycemia group compared to control group according to GCS, while APACHE II and qSOFA showed a statistically significant increase in hyperglycemia group compared to control group (Table 3). 
Table (3): Comparison between control group and hyperglycemic group according to scoring system

\begin{tabular}{|c|c|c|c|}
\hline $\begin{array}{ll}\text { Scoring system } & \text { Groups } \\
\end{array}$ & $\begin{array}{c}\text { Control Group } \\
(\mathbf{n}=\mathbf{2 0})\end{array}$ & $\begin{array}{l}\text { Hyperglycemic } \\
\text { Group }(\mathbf{n}=\mathbf{8 0})\end{array}$ & p-value \\
\hline \multicolumn{4}{|l|}{ Glasgow Coma Score (GCS) \# } \\
\hline Mean \pm SD & $12.25 \pm 0.97$ & $9.85 \pm 1.63$ & \multirow{2}{*}{$<.001$} \\
\hline Range & $11-14$ & $5-12$ & \\
\hline \multicolumn{4}{|l|}{ APACHE II\# } \\
\hline Mean \pm SD & $15.75 \pm 2.63$ & $22.85 \pm 4.31$ & \multirow{2}{*}{$<.001$} \\
\hline Range & $12-21$ & $10-37$ & \\
\hline \multicolumn{4}{|l|}{ qSOFA\# } \\
\hline Mean \pm SD & $1.75 \pm 0.72$ & $2.75 \pm 0.44$ & \multirow{2}{*}{$<.001$} \\
\hline Range & $1-3$ & $2-3$ & \\
\hline
\end{tabular}

Using: \#Independent Sample t-test

There was a statistically significant increase in mean of hyperglycemia group compared to control group according to RBS and IR (Table 4).

Table (4): Comparison between control group and hyperglycemic group according to RBS and IR

\begin{tabular}{|c|c|c|c|}
\hline $\begin{array}{ll}\text { Variables } & \text { Groups } \\
\end{array}$ & $\begin{array}{c}\text { Control Group } \\
(\mathbf{n}=20)\end{array}$ & $\begin{array}{l}\text { Hyperglycemic } \\
\text { Group }(n=80)\end{array}$ & p-value \\
\hline \multicolumn{4}{|l|}{ Random blood sugar (RBS) (g/dL) } \\
\hline Median (IQR) & $106(16)$ & $410(115)$ & \multirow[b]{2}{*}{$<0.001$} \\
\hline Range & $76-136$ & $180-605$ & \\
\hline \multicolumn{4}{|l|}{ Insulin resistance (IR) $\$$} \\
\hline Median (IQR) & $0.06(0.45)$ & $1.3(1.5)$ & \multirow{2}{*}{$<0.001$} \\
\hline Range & $0.0099-0.1$ & $0.04-4.6$ & \\
\hline
\end{tabular}

Using: \#Independent Sample t-test; $\$$ Mann-Whitney test

A statistically significant increase was found in mean of hyperglycemia group compared to control group according to duration of ICU stay (days), Insulin therapy, AKI and hypoglycemia and outcome (Table 5). 
Table (5): Comparison between control group and hyperglycemic group according to outcome

\begin{tabular}{|c|c|c|c|}
\hline $\begin{array}{l}\text { Outcome } \uparrow \\
\text { Groups }\end{array}$ & $\begin{array}{l}\text { Control } \\
\text { Group } \\
(\mathbf{n}=20)\end{array}$ & $\begin{array}{l}\text { Hyperglycemic } \\
\text { Group }(\mathbf{n}=\mathbf{8 0})\end{array}$ & p-value \\
\hline \multicolumn{4}{|l|}{ Duration of ICU stay (days)\# } \\
\hline Mean \pm SD & $9.80 \pm 4.24$ & $14.74 \pm 6.90$ & \multirow{2}{*}{0.003} \\
\hline Range & $1-21$ & $6-67$ & \\
\hline Insulin therapy & $2(10.0 \%)$ & $32(40.0 \%)$ & 0.023 \\
\hline Acute kidney injury (AKI) & $0(0 \%)$ & $14(17.5 \%)$ & 0.039 \\
\hline Interstitial lung disease (ILD) & $1(5.0 \%)$ & $15(18.8 \%)$ & 0.134 \\
\hline Chronic lung disease (CLD) & $2(10.0 \%)$ & $19(23.8 \%)$ & 0.177 \\
\hline Chronic kidney disease (CKD) & $4(20.0 \%)$ & $6(7.5 \%)$ & 0.096 \\
\hline Stroke & $1(5.0 \%)$ & $5(6.3 \%)$ & 0.833 \\
\hline Pneumonia & $2(10.0 \%)$ & $1(1.3 \%)$ & 0.04 \\
\hline Ischemic heart disease (IHD) & $1(5.0 \%)$ & $9(11.3 \%)$ & 0.405 \\
\hline $\begin{array}{l}\text { Chronic obstructive pulmonary } \\
\text { disease (COPD) }\end{array}$ & $1(5.0 \%)$ & $9(11.3 \%)$ & 0.405 \\
\hline Heart failure (HF) & $1(5.0 \%)$ & $0(0.0 \%)$ & 0.144 \\
\hline \multicolumn{4}{|l|}{ Outcome } \\
\hline Alive & $19(95.0 \%)$ & $56(70.0 \%)$ & \multirow{2}{*}{0.021} \\
\hline Died & $1(5.0 \%)$ & $24(30.0 \%)$ & \\
\hline Normal & $9(45.0 \%)$ & $2(2.5 \%)$ & $<0.001$ \\
\hline
\end{tabular}

Using: \#Independent Sample t-test; †Chi-square test

\section{DISCUSSION}

Hyperglycemia has long been recognized as a common occurrence in critically ill patient, even without history of D.M. Stress hyperglycemia is usually defined as nearly detected hyperglycemia $>200 \mathrm{mg} / \mathrm{dl}$ which resolve after resolution of acute illness (Fayed et al., 2015).

This study demonstrated that there was no statistically significant difference between groups according to age and sex. On the other hand, the study group showed a significant increase regarding CRP compared to the control group. A previous study by Sourris et al. (2009) showed that inflammatory markers such as CRP have been related to the development of insulin resistance and type 2 diabetes. Ford E. had also established that CRP levels are higher in people with diabetes and associated with increased $\mathrm{HbA1c}$ in people without diabetes.

Sourris et al. (2009) made a step further with the finding that among people with established diabetes, at successively higher levels of $\mathrm{HbA1c}$, the percent of people with CRP $>0.30 \mathrm{mg} / \mathrm{dl}$ is significantly higher. The mean implications of these findings are that inflammation may not only be implicated in the development of diabetes, but also in ongoing levels of hyperglycemia once diabetes is established.

Gelaye et al. (2010) found links between CRP and insulin resistance. The study has related hyperglycemia to inflammation by demonstrating simultaneous inflammation, endothelial dysfunction and insulin resistance at the physiologic level. 
In the current study, hemodynamic parameters, presence of risk factors and comorbid diseases revealed those patients with hyperglycemia had lower SBP and DBP. These results were in agreement with Pandey et al. (2014) who found that when the severity of disease increases in sepsis, the variability in the values of both SBP and DBP increase. They also found that APACHE II score was positively correlated with variability in the values of both SBP and DBP. This indicated that when APACHE II increased, blood pressure varied too.

Also, the comparison between the two groups revealed that HR was higher in patients of the hyperglycemic group. These results agreed with Pong et al. (2019) who concluded that variability in HR was correlated with increased illness severity as calculated using APACHE II score.

In agreement with Kushimoto et al. (2013), our results illustrated that elevated temperature was not associated with an increase in disease severity or risk of mortality.

According to RR and $\mathrm{ABG}$, this study showed no significant difference between the two groups. These results were explained by Ganesh et al. (2016) who mentioned that, in patients with sepsis and septic shock, high anion gap metabolic acidosis is the dominant blood gas anomaly in addition to lactate.

This study also showed that patients with hyperglycemia had a significant lower GCS which may be explained by severity of sepsis in those patients. This was in agreement with Chaudhry and Duggal (2014) who proved that advanced sepsis can cause brain damage. Milder cases may recover without neurological problem; these cases may be related to the reversible mechanisms of what is called sepsis-associated encephalopathy (SAE), however more advanced cases of sepsis may have neuron- killing complications.

In this study, data of disease severity which was represented by hemodynamic parameters, need of mechanical ventilation and vasoactive support were significantly worse in hyperglycemic group which was reflected also in worse APACHE II score. This was in agreement with Chaudhry and Duggal (2014) who proved that sepsis ultimately leads to tissue injury and multi-organ dysfunction for example, circulatory shock and acute lung injury.

The present study showed a significant increase in insulin resistance in the hyperglycemic patients compared to the control group. In support, Czech (2017) suggested two working hypotheses for increased insulin resistance in hyperglycemic patients. Gram-negative infection further impairs both glucoseand insulin- mediated regulation of glucose production and utilization in hyperglycemia, and the sepsis-induced increase in circulating concentrations of counter-regulatory hormones are responsible for the increased insulin resistance in sepsis.

Our study showed a statistically significant increase in mean of hyperglycemia group compared to control group according duration of ICU stay. In support, Marik and Bellomo (2013) mentioned that the median duration of ICU and hospital length of stay was longer in patients with stress hyperglycemia. They added that severe 
stress hyperglycemia may be harmful due to its effects on serum osmolarity. In addition, severe hyperglycemia exceeds the renal threshold, resulting in an osmotic diuresis and volume depletion.

In terms of AKI, this study reported a higher incidence in hyperglycemic patients. This was in agreement with Wang et al. (2017) who explained that stress hyperglycemia can impair renal function by increased activation of NFkappa B and oxidant levels with the stages of sepsis, which leads to a much higher incidence of AKI.

Our study clarified that septic patients with hyperglycemia had a significant higher mortality rate. Several studies have demonstrated that sepsis is associated with the activation of inflammation and coagulation, and the activation of coagulation accounts for a large proportion of deaths. In addition, stress hyperglycemia is associated with abnormal coagulation and fibrinolysis to a certain extent.

Venot et al. (2015) showed higher mortality in hyperglycemic patients. The functions of leucocytes, especially polymorpho-nuclear leukocytes (PMN), are impaired by hyper-glycemia. It was reported by several studies that membrane fluidity of PMN were significantly lower in hyperglycemic patients, resulting in the decrease of multiple functions, such as impaired migration, reduced phagocytosis, and intracellular killing capacity, as well as altered chemotaxis.

\section{CONCLUSION}

Stress hyperglycemia with high insulin resistance was strongly associated with adverse outcomes in patients with sepsis who were admitted to the medical ICU. Septic patients with hyperglycemia showed increased incidence of mortality and AKI.

\section{REFERENCES}

1. Chaudhry N and Duggal AK. (2014): Sepsis associated encephalopathy. Advances in Medicine, 215-236.

2. Czech MP. (2017): Insulin action and resistance in obesity and type 2 diabetes. Nature Medicine, 23(7):804-14.

3. Fayed AM, El-Sawy MM, Mahrous AE and Soliman ME. (2015): IL-6 and ITS correlation to stress hyperglycemia in diabetic and nondiabetic critically ill septic patients. Intensive Care Medicine Experimental, 3(1): 1:A304.

4. Ganesh K, Sharma RN, Varghese $J$ and Pillai MG. (2016): A profile of metabolic acidosis in patients with sepsis in an Intensive Care Unit setting. Int J Crit Illn Inj Sci., 6(4):178-181.

5. Gelaye B, Revilla $L$, Lopez $T$, Suarez $L$, Sanchez SE, Hevner K, Fitzpatrick AL and Williams MA. (2010): Association between insulin resistance and C-reactive protein among Peruvian adults. Diabetology \& Metabolic Syndrome, 2(1):1-6.

6. Kushimoto S, Gando S, Saitoh D, Mayumi T, Ogura H, Fujishima S, Araki T, Ikeda H, Kotani J, Miki Y and Shiraishi SI. (2013): The impact of body temperature abnormalities on the disease severity and outcome in patients with severe sepsis: an analysis from a multicenter, prospective survey of severe sepsis. Critical Care, 17: 271-279.

7. Marik PE and Bellomo R. (2013): Stress hyperglycemia: an essential survival response! Crit Care Med., 41(6): e93-4.

8. Nakamura $M$, Oda $S$, sadhir $T$, Watanabe E, Abe R, Nakada T, Morita and Hirasawa H. (2012): Correlation between high blood IL6 level, hyperglycemia, and glucose control in septic patients. Critical Care, 16(58):1-9.

9. Pakhetra LCR, Grag CMK and Suryanarawana AM. (2016): Management of hyper- 
glycemia in critical illness: review of targets strategies. [MJAFL], 67(1)53-57.

10. Pandey NR, Bian YY and Shou ST. (2014): Significance of blood pressure variability in patients with sepsis. World Journal of Emergency Medicine, 5(1):42-46.

11. Pong JZ, Fook-Chong S, Koh ZX, Samsudin MU, Tagami T, Chiew CJ, Wong TH, Ho AF, Ong ME and Liu N. (2019): Combining heart rate variability with disease severity score variables for mortality risk stratification in septic patients presenting at the emergency department. International Journal of Environmental Research and Public Health, 16(10):1725-31.

12. Robba C and Bilotta F. (2016): Admission hyperglycemia and outcome in ICU patients with sepsis. J thorac Dis., 8(7):581-583.

13. Sourris KC, Lyons JG, de Courten MP, Dougherty SL, Henstridge DC, Cooper ME, Hage M, Dart A, Kingwell BA, Forbes JM and de Courten B. (2009): C-Jun NH2terminal kinase activity in subcutaneous adipose tissue but not nuclear factor-kappaB activity in peripheral blood mononuclear cells is an independent determinant of insulin resistance in healthy individuals. Diabetes, 58(6):1259-65.

14.Spindler MP, HO AM, Tridgell d, McCulloch-Oslon M, Gersuk V, NI C, Greenbaum C and Sanda S. (2016): Acute hyperglycemia, IL6 expression in humans. Immunity, inflammation and Disease, 91-97.

15. Venot M, Weis L, Clec'h C, Darmon M, Allaouchiche B, Goldgran-Tolédano D, Garrouste-Orgeas M, Adrie C, Timsit JF and Azoulay E. (2015): Acute kidney injury in severe sepsis and septic shock in patients with and without diabetes mellitus: A multicenter study. PLoS One, 10(5): e0127411.

16. Wang Z, Ren J, Wang G, Liu Q, Guo K and Li J. (2017): Association Between Diabetes Mellitus and Outcomes of Patients with Sepsis: A Meta-Analysis. Med Sci Monit., 23: 35463555 . 
ارتفاع سكر الدم فى مرضي التسمح الدموى ودور مقاومة الانسو لين و علاقته برالنتائج

محمد جلال محمد حسن، جمال بلر، أحمد محمد الأشقر، أشرف أحمد* قسمي الأمراض الباطنة والباثولوجيا الإكلينيكية،، كلية الطب، جامعة الأزهر

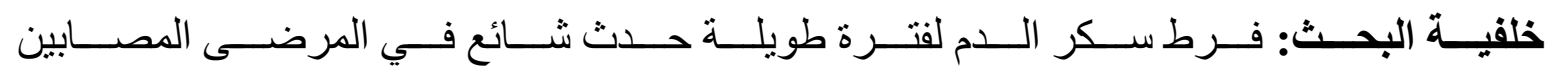
بأمر اض حرجة، حتى بدون تاريخ مرضى للإصـابة بمرض السكر.

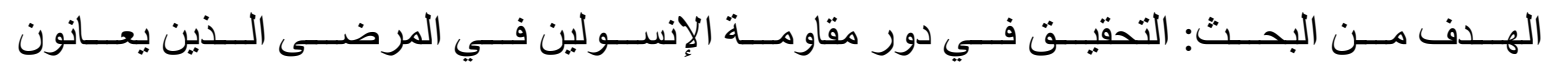

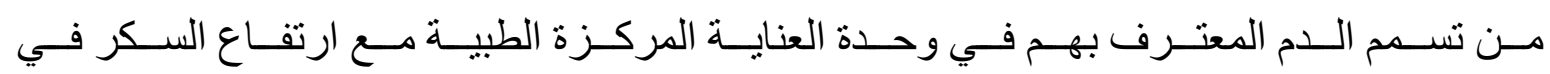
الدم الحاد و علاقته بنتيجة 30 يومًا.

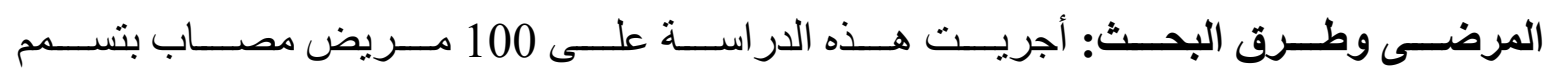

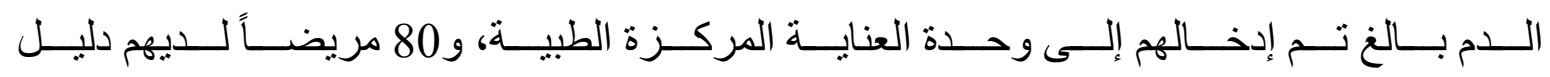
على ارتفاع السكر في الدم و20 مريضاً يعانون من حالة سكر الدم.

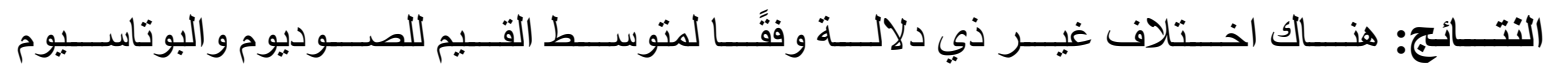

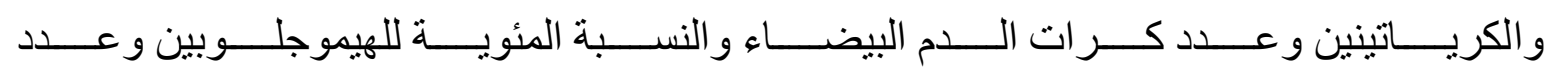

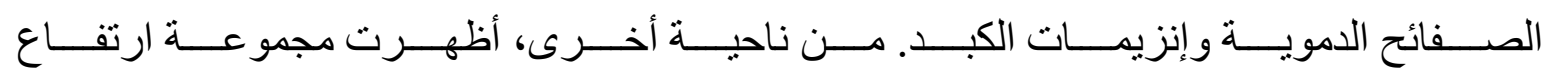

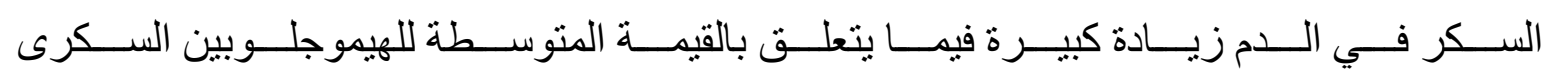

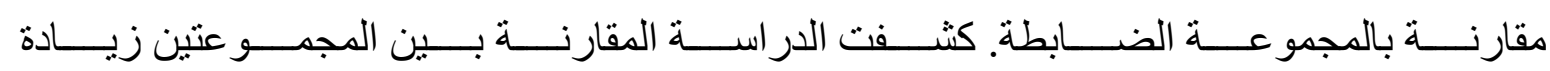

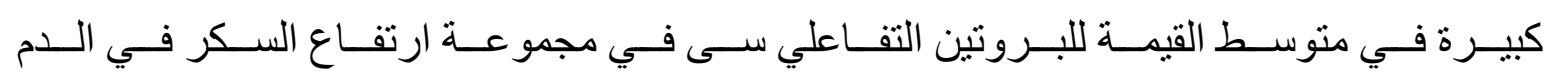

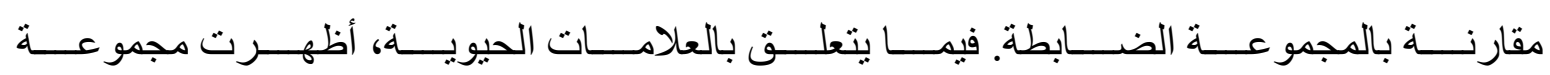

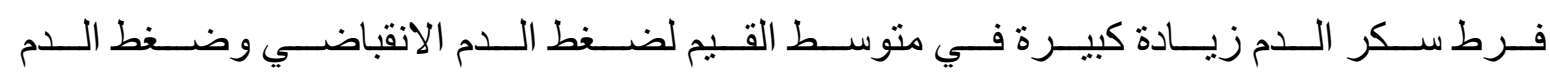

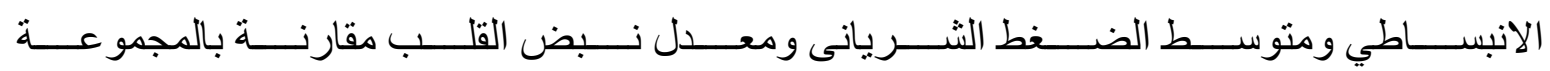

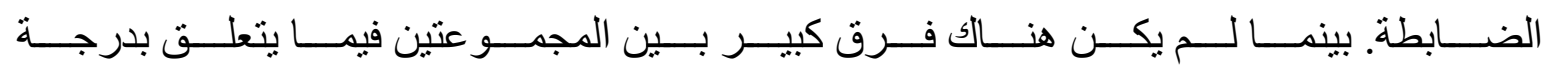

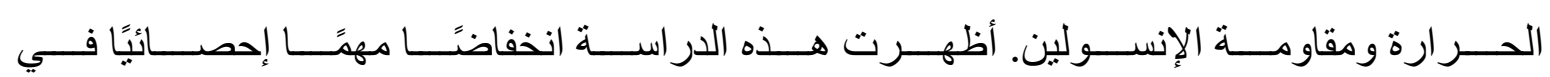

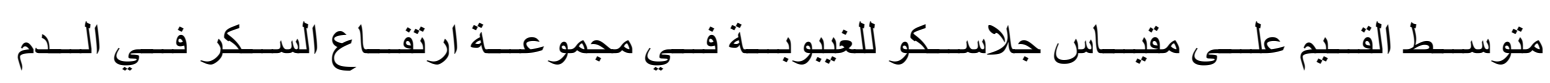

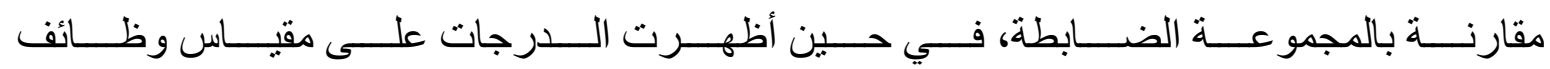

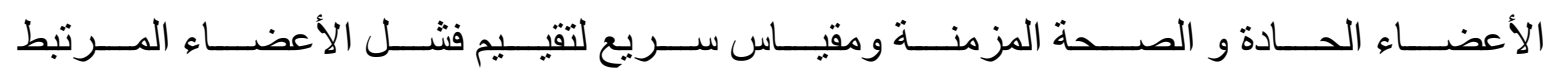




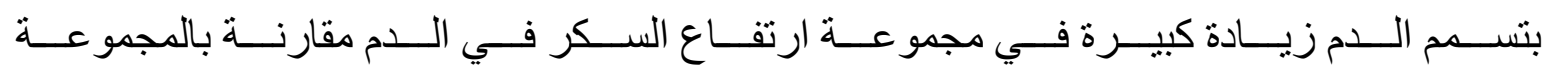

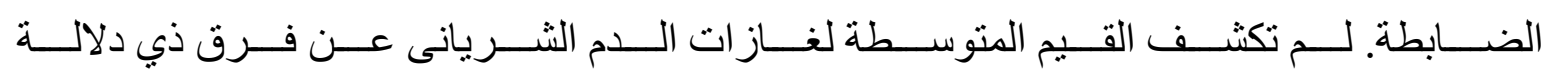

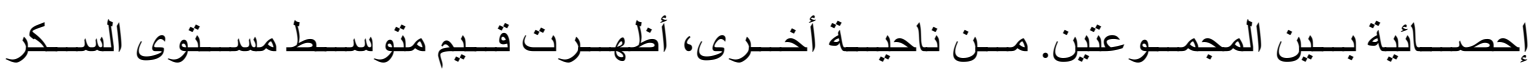

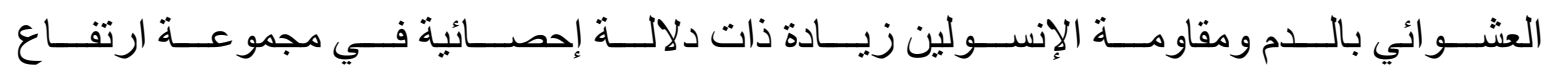

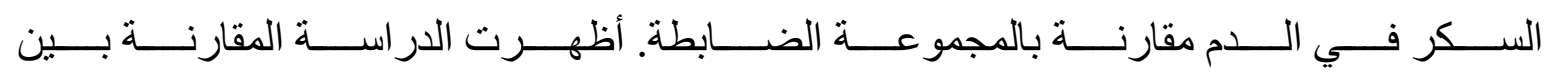

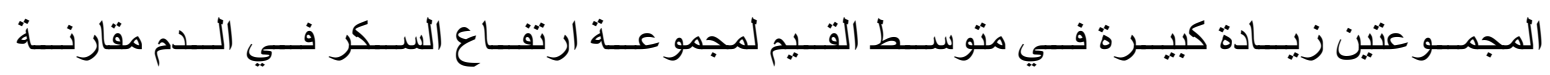

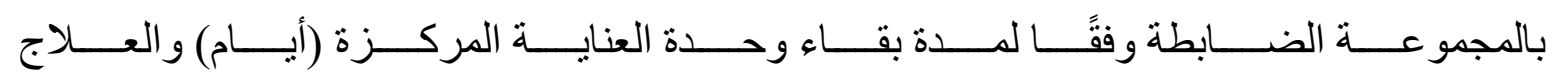

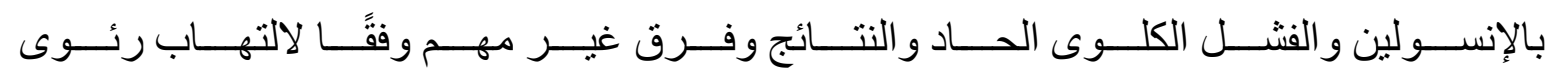

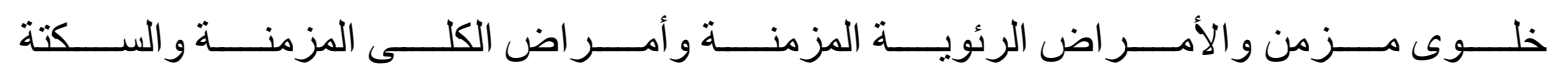

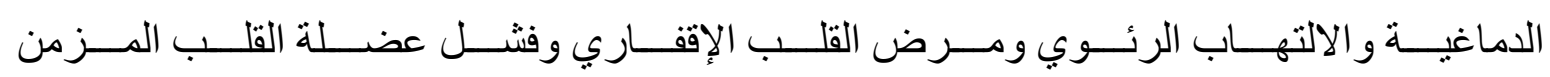
و الانسداد الرئوي المزمن.

الاســتنتاج: فـرط ســكر الــدم مــع ارتفــاع مقاومـــة الإنســولين بــرتبط بقــوة بالنتــائج السـلبية

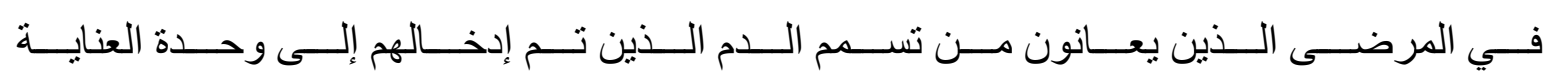
المركـزة الطبيــة. و أظهـر مرضــى تسـمم الــدم الــذين بعـانون مــن ارتفــاع الســكر فـي الــدم زيادة في حدوث الوفيات وفثل كلوى حاد. 